\title{
1979: A (quase) primeira bissexual protagonista em telenovela
}

\section{9: The (almost) first bisexual protagonist in telenovela}

\author{
1979: La (casi) primera bisexual protagonista en telenovela
}

\author{
Guilherme Moreira Fernandes ${ }^{1, a}$ \\ guilherme.fernandes@ufrb.edu.br | https://orcid.org/oooo-0001-6896-4963 \\ ${ }^{1}$ Universidade Federal do Recôncavo da Bahia, Centro de Artes, Humanidades e Letras. Cachoeira, BA, Brasil. \\ a Doutorado em Comunicação pela Universidade Federal do Rio de Janeiro.
}

\section{Resumo}

Este artigo tem como objetivo apresentar e discutir a representação da primeira protagonista bissexual de telenovela. Trata-se de Paloma, da obra Os Gigantes de Lauro César Muniz exibida pela TV Globo entre os anos de 1979 e 1980 na faixa das 2oh. Por meio de uma análise documental, a partir do entendimento da TV de Papel e do Recurso Comunicativo, estudamos a repercussão da identidade bissexual da personagem em jornais e revistas massivos, de cunho geral e especializado. Também consultamos documentos da Divisão de Censura de Diversões Públicas com o objetivo de perceber a interferência censória na telenovela, no tocante à lesbianidade.

Palavras-chave: Comunicação; Jornalismo; Telenovela; Identidade homossexual; Censura.

\begin{abstract}
This paper aims to present and discuss the representation of the first bisexual protagonist of a telenovela. This is Paloma, from the play Os Gigantes by Lauro César Muniz shown by TV Globo between the years of 1979 and 1980 in the band of 8pm. Through a documentary analysis, based on the understanding of the TV de Papel and the Communicative Resource, we study the repercussion of the bisexual identity of the character in mass and specialized newspapers and magazines. Also consulted the documents of the Divisão de Censura de Diversões Públicas with the objective of perceiving the censoring interference in the telenovela, regarding lesbianity.
\end{abstract}

Keywords: Communication; Journalism; Telenovela; Homosexual Identity; Censorship. 


\section{Resumen}

Este artículo tiene como objetivo presentar y discutir la representación de la primera protagonista bisexual de telenovela. Se trata de Paloma, de la obra Os Gigantes de Lauro César Muniz exhibida por la TV Globo entre los años 1979 y 1980 en lo prime time (20h). Por medio de un análisis documental, a partir del entendimiento de la TV de Papel y del Recurso Comunicativo estudiamos la repercusión de la identidad bisexual del personaje en periódicos y revistas masivos, de carácter general y especializado. También se consultó los documentos de la División de Censura de Diversiones Públicas con el objetivo de percibir la interferencia censoria en la telenovela, en lo que se refiere a la lesbianidad.

Palabras clave: Comunicación; Periodismo; Telenovela; Identidad homosexual; Censura.

Este artigo faz parte do dossiê $\mathbf{4 0}$ anos do movimento LGBT: visibilidades e representações.

Contribuição dos autores:

Concepção e desenho do estudo: Guilherme Moreira Fernandes;

Aquisição, análise ou interpretação dos dados: Guilherme Moreira Fernandes;

Redação do manuscrito: Guilherme Moreira Fernandes;

Revisão crítica do conteúdo intelectual: Guilherme Moreira Fernandes.

Declaração de conflito de interesses: não há.

Fontes de financiamento: Coordenação de Aperfeiçoamento de Pessoal de Nível Superior (Capes). Fundação Biblioteca Nacional. Bolsas de Pesquisa.

Considerações éticas: não há.

Agradecimentos/Contribuições adicionais: não há.

Histórico do artigo: submetido: 31 jan. 2019 | aceito: 24 maio 2019 | publicado: 12 set. 2019.

Apresentação anterior: versão preliminar apresentada no III Encontro Regional Sudeste de História da Mídia (2014).

Licença CC BY-NC atribuição não comercial. Com essa licença é permitido acessar, baixar (download), copiar, imprimir, compartilhar, reutilizar e distribuir os artigos, desde que para uso não comercial e com a citação da fonte, conferindo os devidos créditos de autoria e menção à Reciis. Nesses casos, nenhuma permissão é necessária por parte dos autores ou dos editores. 


\section{Introdução}

A telenovela Os Gigantes, de Lauro César Muniz, com direção de Régis Cardoso, foi exibida às 2oh pela TV Globo no período entre 20 de agosto de 1979 e 2 de fevereiro de 1980, com 147 capítulos. Os Gigantes foi uma das mais audaciosas e incompreendidas entre as telenovelas brasileiras. O caldeirão de emoções incluía: crítica às multinacionais, eutanásia, sincretismo religioso, homossexualidade feminina, adultério, suicídio, amor livre e uma protagonista tão livre e bipolar, às vezes neurótica, que não despertou a empatia do público. A jornalista Liane Alves, do jornal O Estado de S.Paulo, ainda incluiu uma relação incestuosa entre Paloma e Freddy durante a infância nesse rol de anseios da telenovela.

Caso a intenção de Muniz fosse a de escrever um romance literário, certamente seria um grande sucesso. No entanto, para uma telenovela que se passou em 1979, foi um grande exercício de subversão. A prometida abertura política dos militares com a derrubada do Ato Institucional n ${ }^{0} 5$ - a longo prazo - não teve grandes modificações na Divisão de Censura às Diversões Públicas (DCDP), órgão extinto apenas em 1988, com a promulgação da Carta Magnai. Além do mais, muitos dos assuntos incluídos na pauta desagradaram a emissora. O mais apontado foi a crítica às multinacionais, materializada na luta do fazendeiro Antônio Lucas (Mário Lago) contra a poderosa Welkson, dirigida por Novak (Perry Salles).

Em entrevista a André Bernardo e Cintia Lopes ${ }^{1}$, Muniz admite ter sido Os Gigantes seu maior fracasso e traz para si a responsabilidade pelo não sucesso. Sabemos, contudo, que outros fatores contribuíram para isso, como a fraca direção de Régis Cardoso ${ }^{\mathrm{ii}, 2}$ e, especialmente, as reclamações de Dina Sfat, que não conseguiu entender Paloma. Outros nomes do elenco, como Susana Vieira, também não gostaram da trama e reclamaram de seus personagens. No caso de Susana, a revista Amiga publicou uma série de entrevistas com a atriz durante quatro edições consecutivas. A atriz, não raras vezes, dizia não gostar de sua personagem Veridiana. Aparentemente, Susana também não a compreendeu em sua magnitude. Paloma e Veridiana eram personagens com alta densidade psicológica, talvez essa característica tenha assustado as atrizes.

Uma das provas da 'birra' que Dina tomou de Paloma pode ser encontrada nesta passagem publicada pela revista Sétimo Céu em que a atriz pede a morte de sua personagem. De fato, Paloma morreu, mas não porque a atriz assim desejou. "Em outras novelas mataram o Salomão Hayalla, o César Reis, porque não matam também essa mulher? Para mim seria melhor a Paloma morrer, assim não precisava gastar dinheiro com psicanalista. Essa personagem me angustia muito, e agora sinto que tenho o direito de não falar, pelo menos isso eu tenho. Prefiro não comentar nada, porque ela muda muito, e tudo o que eu disser parecerá falso depois, porque poderá se transformar”3.

Escrever fortes personagens femininos não é uma novidade nas telenovelas de Lauro. Ao lado de Bráulio Pedroso, Lauro César Muniz também deixou sua contribuição para o gênero. Antes de Beto Rockfeller de Pedroso - telenovela tida como um divisor de águas na teledramaturgia brasileira por inserir a figura de um anti-herói como protagonista e utilizar diálogos coloquiais -, Lauro escreveu para a Excelsior a telenovela Ninguém crê em mim (1966), tida como a primeira a apresentar diálogos com tom de coloquialidade. O autor ainda escreveu O Morro dos Ventos Uivantes na Excelsior, Estrelas no Chão na TV Tupi de São Paulo, e As Pupilas do Senhor Reitor, Os Deuses estão mortos e 40 anos depois na TV Record. Em 1972, migra para

i Fernandes ${ }^{4}$, em sua tese de doutoramento, desenvolve a hipótese de que o maior e menor rigor da censura em questões morais - foco único (em nível legal) da Divisão de Censura de Diversões Públicas (DCDP) - estava mais atrelado aos 'donos' da pasta (Ministro da Justiça, Chefe da Polícia Federal, Diretor da DCDP) do que ao próprio 'programa' dos generais-presidentes. Desta forma, é perceptível que no hiato de 1979 a 1981 algumas temáticas que antes e também depois não seriam permitidas pela censura à TV (em especial, à teledramaturgia) fossem apresentadas. Além da permissão de abordagem de identidade bissexual em 'Os Gigantes', o mesmo período trouxe temas inovadores em diversos produtos, como a telenovela 'Brilhante' e o seriado 'Malu Mulher'.

ii Tal situação pode ser verificada na seguinte passagem da autobiografia do diretor: "A novela de Lauro César tinha momentos de grande dramaticidade e momentos de situações embaraçosas, em que tanto os atores quanto eu ficávamos sem saída. Os personagens, constantemente, agiam sem lógica. Dina Sfat, protagonista, várias vezes, olhou para mim e perguntou: '- E agora, o que eu faço?'. E eu: '- Só falta você levitar'. Era muito difícil para ela fazer uma mulher apaixonada por dois homens ao mesmo tempo (Cuoco e Tarcísio). Eram também as atitudes dela. A novela não foi bem, não fez sucesso. [...]. Lauro César tentou me responsabilizar pelo possível fracasso. Anos depois, nos encontramos no Maracanã e ele admitiu que o erro tinha sido dele. Ele tentou um tipo de dramaticidade, mas foi vencido pela credibilidade de cada um dos seus personagens"2. 
a Rede Globo e substitui Bráulio Pedroso em O Bofe. Carinhoso (1973) foi seu primeiro grande sucesso, uma romântica telenovela das 19h. É com Escalada (1975) e O Casarão (1976) que adquire prestígio com a crítica especializada. O Casarão, inclusive, inovou ao contar uma história, de forma simultânea, envolvendo três épocas distintas.

O enredo de Os Gigantes tinha como eixo a figura de Paloma (Dina Sfat). Ao saber da gravidade da doença do seu irmão gêmeo Freddy, Paloma, que era correspondente internacional na Itália, retorna ao Brasil. Ao chegar em Pilar (pequena cidade [fictícia] fluminense) abala a vida dos 'amigos' Chico (Francisco Cuoco) e Fernando (Tarcísio Meira), antigos namorados. Fernando é casado com Vânia (Joana Fomm) e Chico, noivo de Helena (Vera Fischer). Paloma recebe uma fita K7 (e também livros sobre eutanásia) com gravações de Freddy lamentando o seu estado de saúde, dizendo que não quer continuar a viver e pedindo que a irmã desligue os aparelhos que o mantém vivo. Paloma atende o pedido do irmão e comete o crime da eutanásia. Veridiana (Susana Vieira), sua cunhada, abalada com a morte do marido, aborta de forma espontânea o filho que estava esperando. Algum tempo depois, descobre as gravações de Freddy e acusa Paloma de ter matado o próprio irmão. Inicia-se, aí, a batalha judicial entre as duas que vai se desenvolver até a última semana do folhetim televisivo.

Ao saber que Paloma tinha retornado ao Brasil, Chico e Fernando começam a cortejar a jornalista que cede ao charme dos quarentões. Ora nos braços de Chico, ora nos de Fernando, Paloma não consegue decidir por um deles. Ela era ao mesmo tempo liberal e libertina, não seguia as convicções da moralidade 'vigente'. O autor, em entrevista enviada aos jornais, afirmava que Paloma era "uma mulher ampla, abrangente, total. Alguém que jamais é o objeto da ação, mas sim o sujeito. Uma pessoa que decide tudo sobre ela mesma, e não aceita que digam o que deve ser feito ${ }^{5}$.

Paloma era sempre a 'causa' dos problemas, os demais personagens eram coadjuvantes em sua ação. Ela se mostrava distante (embora próxima fisicamente) de Fernando e Chico, e com Renata (Lídia Brondi), com quem 'deveria' ter um romance, se mostrou dominadora da situação. De certa forma, Paloma foi o mote de todos os conflitos da novela, talvez por isso sua personagem tenha se desgastado e não tenha gerado a empatia do público. No decorrer da telenovela, o perfil da personagem sofreu algumas modificações sem o consentimento do autor.

A persona de Paloma era dúbia, de múltiplas leituras possíveis, e a liberdade, sua característica principal. Pelo roteiro a que tivemos acesso - e levando em conta o formato 'aberto' da telenovela - nos parece complicado determinar uma identidade de orientação sexual fora dos binarismos. Seria Paloma uma lésbica? As aproximações com os ex-namorados fariam dela uma bissexual? No âmbito da psicologia social, como observa Adriana Nunan ${ }^{6}$, a identidade de self, na esfera da orientação sexual, é passível de múltiplas e contraditórias etapas, pois ao longo da vida essas questões vão se desenhando e adquirindo novos contornos. Ainda conforme a autora, a identidade é construção e percepção da própria pessoa.

Nesse sentido, nos parece mais seguro apontar uma bissexualidade da personagem. Com isso podemos inferir que a liberdade era de tal forma propagada que um relacionamento amoroso com outra mulher não era descartado. Em relação aos outros dois relacionamentos 'heterossexuais' que a personagem manteve durante a telenovela, não temos segurança para afirmar um sentimento de desejo, paixão ou até mesmo de amor. Tudo poderia ser mera convenção social seguida pela personagem, o que também ressalta suas ambiguidades.

Pelo fato de Paloma ter se relacionado com homens (Chico e Fernando) ao mesmo tempo em que se mostrou disposta a viver um romance com uma mulher (Renata), designamos uma bissexualidade da personagem. Contudo, não é possível fazer tal afirmação de forma categórica, ao pensar que a heterossexualidade é compulsória. Dessa forma, ao longo deste texto, quando nos referirmos à aproximação de Paloma e Renata, trataremos como relação lésbica e pelo fato de a personagem se relacionar com homens, inferimos - a comodi - sua bissexualidade. 


\section{Os anos 1970 e a homossexualidade}

Retratos no Brasil na década de 1970 já foram palco de múltiplos estudos envolvendo questões sociais, culturais, políticas e censórias. Maria Rita Kehl7 aponta a existência de duas décadas nos anos 1970, sendo que a primeira começou com a promulgação do Ato Institucional no 5 , o AI-5, em 1968 - coincidentemente o ano que marcou o início da modernização da telenovela brasileira (com a exibição de Beto Rockfeller). O AI-5 foi responsável por fechar o congresso nacional e, junto com a Lei de Segurança Nacional, instituía a censura à imprensa. A outra década apontada por Kelh diz respeito tanto à ascensão da televisão como principal meio de comunicação como também ao advento de uma contracultura com modificações no comportamento, costumes e modos de vida, especialmente dos jovens de classe média urbana e universitária, como ressalta a psicanalista.

A respeito da ascensão da televisão, Esther Hamburger ${ }^{8}$ argumenta que apesar do veículo ter sido inaugurado oficialmente em 1950, seus primeiros 20 anos foram incipientes. Já nos anos 1970 "sob censura e contando com infraestrutura técnica fornecida pelo regime militar, a televisão se viabiliza como atividade lucrativa, umbilicalmente ligada ao desenvolvimento de ramos econômicos relacionados, como a publicidade e a pesquisa de mercado, e de mercado consumidor forte" . A pesquisadora ainda explica que a teleficção se consolidou como carro-chefe de uma indústria cultural com características próprias. Igor Sacramento ${ }^{9}$ também aponta o papel do regime militar frente à televisão, apresentando que se por um lado a TV se beneficiou do desenvolvimento tecnoindustrial (a criação da Embratel em 1975, a TV em Cores em 1973, a redução do preço do aparelho receptor etc.), por outro ela sofreu imposição de criar uma nova imagem para o brasileiro: "la orientación de la televisión debería fortalecer la moral conservadora hegemónica: la consolidación de la imagen idílica de una sociedad basada en los valores cristianos, adictos a la familia, civilizados y modernos, aboliendo el 'bajo nivel' que había dominado las estaciones",iiii.

Mesmo com essas 'orientações', podemos perceber alguns avanços temáticos, especialmente no universo das (homo)sexualididades, reproduzidos via ficção seriada. Hamburger ${ }^{8}$ e Maria Immacolata V. Lopes ${ }^{10}$ apontam a telenovela a partir de 1970 como responsável por narrar a nação e apresentar ao brasileiro desterritorializado (reflexo do êxito rural e da migração nordestina para o Sudeste) uma imagem glorificada, o que se traduz no processo de identificação e projeção identitária para uma realidade menos crua.

Se compararmos com as décadas anteriores, conhecidas como 'anos dourados', perceberemos que ao menos para uma parcela da população (sobretudo jovens de classe média urbana e universitários) a sexualidade deixou de ser um tabu. A década de 1970 ficou conhecida como o período de 'liberação sexual', como relembra Kehl7, sendo a industrialização dos anticoncepcionais um forte motor: "Beneficiou-nos, mas não deixou de cobrar o seu preço. Foi muito bom para as moças da minha geração perder a virgindade sem culpa, fora do casamento. Foi bom poder diversificar a experiência sexual, ter parceiros diferentes, aprender, perder preconceitos, perder o medo e, para as mulheres, saber que o primeiro homem não tem de ser necessariamente o definitivo. Mas tentamos abolir a posse e o ciúme das relações amorosas e com certeza não conseguimos; não reprimíamos a atração que sentíamos pelo amigo que dormia no quarto ao lado, mas tínhamos de esconder o ciúme e a dor que sentíamos quando era o nosso parceiro que fazia a mesma coisa [...]”7.

Embora Kehl não aborde a questão da homossexualidade, sabemos que ela também estava presente nesse processo de liberação sexual - restrito aos grupos descritos por ela - e já não precisava ser escondida por meio de clubes e guetos como acontecia nas décadas anteriores ${ }^{\text {iv }}$.

iii "A orientação da televisão deveria fortalecer a moral conservadora hegemônica: a consolidação da imagem idílica de uma sociedade baseada nos valores cristãos, dedicados à família, civilizados e modernos, abolindo o 'baixo nível' que dominou as estações". (tradução nossa).

iv Em termos macros, ainda na contemporaneidade, não se pode falar em liberação sexual da mulher e nem das homossexualidades. O machismo e a homofobia permanecem com graus de manifestações distintas. A demarcação apenas ressalta que um grupo (urbano, classe média, universitários) pôde vivenciar o hedonismo. 
O primeiro estudo científico sobre a homossexualidade no Brasil foi realizado por José Fábio Barbosa Silva $^{11}$ no final dos anos 1950, tendo como corpus a cidade de São Paulo. Defendido como monografia de especialização, sob a orientação de Florestan Fernandes, o trabalho só foi publicado em 2005. As análises de Silva sobre a homossexualidade em São Paulo nos chamam a atenção por descrever características da sociabilidade homossexual na década de 1950, bem diferente do que encontramos em etnografias realizadas nas décadas seguintes. De acordo com Silva: "Uma observação ligeira da visibilidade do homossexual poderia indicar a existência de um número reduzido de indivíduos isolados que manifestam comportamentos sociais tidos como homossexuais. Essas observações casuais não são, no entanto, suficientes para tornar visível toda a complexidade do grupo minoritário, em que a maior parte dos membros não evidencia características de comportamento compatíveis com o estereótipo [efeminado] majoritário da figura homossexual" ${ }^{\prime 1}$.

A razão diagnosticada por Silva é justamente a marginalidade social do grupo. Desta forma, a grande maioria dos homossexuais apresentava comportamentos sociais tidos como masculinos, e a vivência da homossexualidade era restrita a alguns pontos da cidade, em especial o entorno da Praça da República. Silva ainda aponta que na maior parte do ano o grupo se restringe a guetos, contudo há uma visibilidade dos homossexuais em ocasiões como o carnaval, o baile do Teatro João Caetano e do Recreio, no Rio de Janeiro - "é a partir da observação dessas situações isoladas que a maioria começa a perceber a importância numérica e atuante do grupo minoritário" ${ }^{11}$. Foi a partir da década de 1970 que os homossexuais começaram a sair do gueto e a adquirir outros espaços de sociabilidade e visibilidade em cenários midiáticos, conforme atesta Edward MacRae ${ }^{12}$, em texto originalmente publicado em 1983. "Talvez tenha sido no início da década de 1970, com a volta da Europa de Caetano Veloso e ano ênfase que os antigos tropicalistas passaram a dar à androgenia, que o comportamento homossexual começou a sair dos recintos fechados para tornar-se público. Surgiram depois os Dzi Croquetes e o conjunto Secos e Molhados, com o cantor Ney Matogrosso borrando as linhas demarcatórias entre os sexos. Somem-se a isso notícias vindas da Europa e dos Estados Unidos falando sobre a 'revolução gay' que estaria acontecendo nesses lugares. Em fevereiro de 1976, começou a sair no Última Hora de São Paulo uma coluna editada por Celso Curi, a 'Coluna do Meio', com informações, fofocas e piadas sobre o mundo gay, além de um 'correio elegante'. [...]. O grande marco mesmo foi o aparecimento do jornal Lampião, cujo número experimental circulou pela primeira vez em abril de $1978{ }^{\prime \prime 2}$.

Além dos aspectos mencionados por MacRae, temos outros indícios para mostrar a importância da homossexualidade no decorrer da década de 1970. No universo cinematográfico, recorremos à pesquisa de Moreno ${ }^{13}$, que encontrou 127 títulos de filmes brasileiros que trazem personagens homossexuais em um levantamento concluído em 1996. Os títulos foram divididos por décadas: 1920 (um título), 1930 (nenhum), 1940 (três títulos), 1950 (três títulos), 1960 (treze títulos), 1970 (sessenta e um títulos), 1980 (quarenta e quatro títulos), 1990 (até 1996, três títulos). Deste levantamento foram excluídos documentários (inclusive os de longa-metragem), curtas-metragens e filmes de sexo explícito. O levantamento nos mostra que mais de $48 \%$ dos filmes que apresentam personagens homossexuais foram produzidos na década de 1970 .

Algo similar também pôde ser verificado analisando o teatro. Em matéria publicada no jornal 'Lampião', como recorda Delcio Lima, nos deparamos com a seguinte manchete: “O teatro é uma arte gay?' - perguntou, menos com surpresa e mais com satisfação, o título de uma longa matéria do 'Lampião' [...] ao término de um semestre em que 11 dos 25 espetáculos teatrais exibidos no eixo Rio-São Paulo apoiaram a temática homossexual”14. O autor ainda prossegue: "A produção nacional de textos homoeróticos para o teatro é igualmente expressiva, com tendência a ser ampliada, não obstante de qualidade discutível. Alguns, na verdade, são de baixo nível, grotescos e ridículos. [...]. Não falta, portanto, produções nem quem a consuma até com voracidade. As peças homossexuais lotam os teatros e o público, que, nos anos 6o, se manifestou selvagem na repulsa ao beijo que Leonardo Vilar deu na boca de Miguel Carrano, em 'Panorama Visto da Ponte', é o mesmo que, hoje, acompanha com tensão lúbrica as simulações de sexo explícito entre os que protagonizam papéis gays e lésbicas. 'Muitos pares de homens e mulheres entram no teatro bem comportadinhos, veem a peça e saem em meio às mais ternas manifestações de carinho. A temática homoerótica ajuda 
muita gente a assumir a homossexualidade' - comentou, irônico, Pedro Paulo Cava, inteligente diretor de espetáculos teatrais em Belo Horizonte"14.

Música, cinema e teatro também são diversões públicas, logo precisavam passar pelo crivo da censura. Contudo, a lógica das produções é diferente das veiculadas pela televisão, que adentra, sem pedir licença, na casa das pessoas. Sendo assim, as cenas explícitas de afeto homossexual veiculadas pelo cinema e pelo teatro não tiveram eco na televisão. No entanto, importantes papéis foram direcionados aos homossexuais. Ainda na década de 1960 - época em que os teleteatros eram as produções mais nobres - três telepeças trouxeram personagens homossexuais. Em relação às telenovelas, antes da exibição de Os Gigantes, a TV Globo mostrou homossexuais em: Assim na terra como no céu (1970), O Rebu (1974), O grito (1975), O astro (1977), Dancin’ Days (1978) e Marron Glacé (1979). Destas tramas, O Rebu apresentou um homossexual como protagonista, além de narrar o amor de duas lésbicas ${ }^{15}$.

Para encerrar esse tópico, ainda chamamos a atenção para dois fatores circunstanciais. Conforme ressaltam Júlio Simões e Regina Facchini: “O arco de expressões e identificações de homossexualidades havia se expandido e se diversificado em meio a um período fervilhante de mudanças sociais e inovações culturais, que culminariam no grande movimento de contestação do regime militar e abririam caminho, também, para a expressão de um movimento político homossexual, que entrava em cena, em 1978, com a publicação do jornal 'Lampião’ e a fundação do grupo Somos"16.

Desta forma, no período de exibição da telenovela em questão já existia a formação de um 'movimento' homossexual, respondendo demandas de parte da sociedade, bem como publicações jornalísticas voltadas para o público. Ademais, outro fator pouco mencionado contribuiu para essa abordagem temática via televisão - Petrônio Portella era o Ministro da Justiça. Portella, nomeado pelo general-presidente João Baptista Figueiredo, permaneceu no cargo durante o período de 15 de março de 1979 (data da posse de Figueiredo) até 6 de janeiro de $1980^{v}$ (data de seu falecimento). Na direção geral do Departamento de Polícia Federal, permaneceu Moacyr Coelho. E, para substituir Rogério Nunes na chefia da Divisão de Censura às Diversões Públicas (DCDP), foi nomeado José Vieira Madeira. Ao contrário de todo o período de atuação da DCDP, o momento em que Portella e Madeira eram os responsáveis pela censura de diversões públicas foi caracterizado por uma época mais branda de atuação censória. Dentre as produções teleficcionais, destacase a exibição do seriado Malu Mulher que chegou a abordar diversos temas tabus sem uso de subterfúgios, como: homossexualidade (masculina e feminina), divórcio, virgindade, aborto etc.

Dadas essas situações conjunturais, buscamos nos veículos impressos a forma como a personagem fora retratada com o objetivo de perceber o motivo da não concretização do romance entre Paloma e Renata.

\section{Protocolo metodológico: o caminho da pesquisa}

A pesquisa partiu da contestação do professor Adolpho Queiróz"17 a respeito da "TV de Papel”. Entendemos como TV de papel os usos do jornalismo impresso a respeito do que é veiculado na TV, ressignificando a programação televisiva nas páginas dos jornais e revistas. Outro importante conceito para o desenvolvimento desta pesquisa foi a concepção de "recurso comunicativo" desenvolvido pela professora Lopes ${ }^{10}$. Segundo a pesquisadora, a telenovela, além de "narrar a nação"10, traz à baila assuntos que repercutem no cotidiano dos espectadores: "abordar a telenovela como recurso comunicativo é identificá-la como narrativa na qual se conjugam ações pedagógicas tanto implícitas quanto deliberadas que passam a institucionalizar-se em políticas de comunicação e cultura no país. Em outros termos, é reconhecer a telenovela como componente de políticas de comunicação/cultura que perseguem o desenvolvimento da cidadania e dos direitos humanos na sociedade" ${ }^{10}$.

v Após a morte de Portella, o chefe da Casa Civil general Golbery de Couto e Silva, figura emblemática no governo Geisel, assumiu interinamente, por dois dias, o Ministério da Justiça. Na sequência, Ibrahim Abi-Ackel tomou posse no cargo. Neste primeiro momento não houve modificações na estrutura da censura às diversões públicas. 
Ao fazermos uso metodológico dos conceitos de 'recurso comunicativo' e 'TV de Papel', queremos mostrar a forma como os assuntos discutidos na televisão, especialmente na telenovela, ganham repercussão no jornalismo, seja por meio das críticas, das matérias ou do colunismo. Pensar em 'recurso comunicativo' no jornalismo impresso é pensar na exegese desenvolvida pelo jornalista e não na simples menção ao que vai acontecer nas tramas ('os próximos capítulos'), à vida privada dos olimpianos, a divulgação de releases, entre outras notícias cujo foco não seja interpretativo/opinativo dos assuntos discutidos via teledramaturgia.

Nossa pesquisa empírica, orientada pela análise documental ${ }^{18}$, percorreu os principais jornais e revistas massivos de cunho geral e especializado. Assim, lemos os jornais O Globo, Folha de S.Paulo, O Estado de S.Paulo e Jornal do Brasil e as revistas Veja, Istoé, Amiga TV Tudo, TV Contigo e Sétimo Céu, e buscamos todas as referências que encontramos no tocante à homossexualidade dos personagens. Acrescentamos a essa pesquisa uma busca pelos pareceres referentes à telenovela emitidos pela $\mathrm{DCDP}^{19}$ com o intuito de perceber como a Censura contribuiu para a gradual eliminação da temática lésbica em Os Gigantes.

A questão que norteou a pesquisa era a de verificar como foi a percepção da identidade homossexual na mídia impressa e na censura e como isso poderia ter contribuído para o esvaziamento dessa temática na trama.

\section{O recurso comunicativo da homossexualidade na TV de Papel}

Antes de começar as articulações com o material empírico registrado, é importante realizar alguns esclarecimentos sobre Renata (Lídia Brondi), a 'quase' parceira homoafetiva de Paloma. Renata era uma jovem veterinária que chegou ao acaso na cidade de Pilar. No início da narrativa, encontra-se com Fernando (Tarcísio Meira) que estava abalado com a vinda de Paloma. Ao se conhecerem, Renata despertou um forte sentimento em Fernando. Fernando enxergava em Renata a Paloma de sua juventude. Inclusive, apesar de terem vivenciado uma noite de amor, um não sabia o nome do outro. Foi então que Fernando passou a se referir a Renata como 'Paloma'. O que fez, como veremos, alguns críticos se referirem a Renata como 'Palominha'.

O primeiro encontro entre Paloma e Renata também foi narrado de uma forma não comum. Paloma estava acompanhada do Dr. Murilo (Denny Perrier), em seu carro, decidida a deixar Pilar e ir até o Rio de Janeiro para retornar à Itália. Renata, acompanhada do então namorado Polaco (Lauro Corona), estava a caminho de Pilar. A gasolina de Polaco acaba, e eles ficam na estrada esperando um 'socorro'. Passa, então, o carro de Paloma, e ela se dispõe a ajudar os jovens. Mesmo uma não sabendo nada a respeito da outra, uma imediata empatia surge, encenada de uma forma direta e carinhosa. Tempos depois, já em Pilar, há uma série de encontros entre Paloma e Renata. A personagem de Dina Sfat ainda sem saber se decidia por Chico ou Fernando; e a personagem de Lídia Brondi apaixonada pelo personagem interpretado por Tarcísio Meira. Nesse emaranhado de situações, ambas começam a trocar elogios, e há sutis toques no rosto, o que sugere um envolvimento amoroso. Contudo, a relação de Paloma e Renata era algo além, quase transcendental. Paloma se projetava em Renata e a percebia em sua juventude. Renata se impressionava com a força e liberdade de Paloma e a admirava por isso.

Todo esse processo de liberdade de Paloma é narrado na entrevista que a atriz Dina Sfat concedeu à revista Amiga: “[...] Pela primeira vez atuando em novela deste autor, de cara Dina confessa todo o amor que está sentindo por esta mulher maravilhosa, ao mesmo tempo que vai analisando Paloma: [...] 'Paloma é amoral e tem sexualidade sem limites' [...] 'Pela primeira vez na televisão estão colocados problemas mais profundos do ser, da existência e do comportamento de uma mulher. Paloma é uma pessoa amoral que explora sua sexualidade para além dos limites chamados normais. Ela encaminhou sua vida num processo de libertação, de busca de novas formas e novos valores. Mas, a morte do irmão vai fazê-la ter um retrocesso ou assim uma espécie de recaída. Sua volta a Pilar será estonteante para as pessoas do lugar. Ela como que mobiliza, atinge, invade, transforma e contamina cada um'. [...] 'É uma mulher que não teme o futuro nem o presente. Atira-se às coisas sem muitos escrúpulos nem dramas 
de consciência. Aliás, desde a eutanásia até o homossexualismo feminino, muitas outras questões polêmicas deverão aparecer e serão colocadas e distribuídas em Paloma, de forma sutil, bonita e precisa, como nenhuma outra personagem feminina já conseguiu ser. Pelo menos na televisão!"”2o.

Como podemos perceber, nesse primeiro momento, a atriz mostrava-se empolgada com o personagem. Situação essa que se modificou no decorrer da trama. Apesar de afirmar que Paloma não teria "dramas de consciência”, não foi exatamente o que aconteceu. Ela sentia sim o peso da morte do irmão. Contudo, no campo da sexualidade, Paloma era realmente livre. A não decisão por Chico ou Fernando não era uma preocupação da personagem. Renata, com quem viveria um romance, seria mais uma opção sexual/afetiva para a personagem.

Acreditamos que podemos fazer sim o registro da bissexualidade de Paloma, o mesmo não podemos afirmar de Renata. Também em entrevista à revista Amiga, a atriz Lídia Brondi afirma que não existia envolvimento amoroso entre a sua personagem e a de Sfat: “[...] 'Renata, como eu, é uma pessoa em fase de transição. E como eu também, não está pronta. Está sendo feita! Mas tem coisas básicas que, eu sei, não vão mudar. Por exemplo, a identificação com a Paloma, a proximidade das duas, a mesma vida... a mesma cabeça... a mesma falta de medo! E fico chateada quando as pessoas dizem, como já disseram, que há um envolvimento homossexual entre as duas. Não há. O que há é a carência de uma e de outra. Paloma assumindo uma de mãe e Renata, de filha. Muito mais um envolvimento maternal da Paloma do que outra coisa. Sabe, não acho legal! O homossexualismo, para mim, é uma relação menor e, colocado assim na novela, perderia muito da beleza da coisa!'. [...] Lídia diz que não vai haver nenhum envolvimento homossexual entre sua personagem Renata e a de Dina Sfat - Paloma. Para ela, a relação entre as duas não passa de um sentimento puro e ingênuo, o mesmo que mãe e filha!”21.

Não sabemos ao certo as razões da atriz em negar o relacionamento homossexual, admitido pelo autor da trama e também pela atriz Dina Sfat no início da atração. As cenas de envolvimento entre as duas foram cortadas, e a partir do capítulo cinquenta e quatro não foi mais exibida tal conotação. O preconceito da atriz também está expresso em sua fala, ao afirmar que o homossexualismo (sic) é uma relação menor. Comportamento similar, de Dina Sfat, no final de 1981, também chamou a atenção da imprensa após uma entrevista nas páginas amarelas da Revista Veja ${ }^{22}$. Àquela época, a atriz destacava a beleza do amor heterossexual e reclamava das personagens femininas no teatro. Nosso objetivo, no entanto, não é o de mostrar a visão das intérpretes sobre a homossexualidade, mas com tal informação podemos considerar que o esvaziamento dessa temática talvez tenha relação direta com o entendimento das atrizes sobre as personagens.

A atriz Cleide Blota, que interpretava a mãe de Renata, também declarou sobre o não envolvimento amoroso de sua filha com a protagonista: “Cleide Blota, a Selma, mãe da Renata em 'Os Gigantes’, dá a sua opinião sobre Paloma: 'A tendência dela é a de se destruir. Na verdade, não vai acontecer essa aproximação amorosa entre ela e Renata, como estão dizendo por aí. Acho que a aproximação será afetiva pois Paloma vê Renata como uma continuação dela e acaba deixando tudo em suas mãos"”23.

Outra questão abordada, inclusive por Muniz, foi o fato de Paloma se autoprojetar em Renata, não exatamente como um sentimento de mãe e filha, e também não necessariamente como um romance lésbico, mas o fato de perceber em uma pessoa o seu ser, sua juventude. É perceber que aquela pessoa representa o que você já foi um dia. Em entrevista ao jornal O Globo, à época de lançamento do melodrama, Muniz declara que Renata é a única personagem capaz de tirar um pouco o brilho de Paloma: “[...] - Ele [Antônio - Mário Lago] poderá ofuscar o brilho da personagem Paloma? - Não. Somente uma personagem feminina, Renata (Lídia Brondi), pode diminuir o brilho de Paloma, justamente porque ela reconhece na Renata todo o potencial para se transformar em numa nova Paloma. - Você colocando em xeque alguns valores morais e situações delicadas, não estaria correndo um sério risco de a novela fracassar, em termos de público? -Acho que 'Os Gigantes' vai conseguir menos audiência que as outras novelas. Ela vai encontrar muita resistência por parte do público, não só por abordar temas como a eutanásia, mas também por causa da personalidade de Paloma. Mas estamos cientes disso. Já fizemos 
várias reuniões para analisar o problema. Mas Paloma é tão fascinante que vai envolver o telespectador e provocar uma revisão daqueles valores. Ela vai passar por cima de tudo isso como um trator" ${ }^{24}$.

O romance entre as duas aconteceria justamente por essa aproximação, essa projeção identitária. Mesmo com o esvaziamento desta parte do enredo, críticos e colunistas perceberam algumas sutilezas do relacionamento entre as personagens. Eis os exemplos que encontramos: 1) “Assim, nos primeiros capítulos, a ‘doutora Renata' parece reviver Maria Schneider em 'O último tango em Paris', quando encontra-se com o fazendeiro Fernando (Tarcísio Meira) num apartamento para alugar. A semelhança, contudo, parou no aspecto imobiliário da transação. Algumas noites mais adiante, nos próximos dias, ela estará diante da própria 'Paloma' (Dina Sfat), vivendo encontros tão insinuantes que ameaçam surgir o primeiro casal feminino da televisão brasileira” ${ }^{25}$. 2) "Palominha tem nome: Renata. Ela está em que lar? Em capítulos futuros o autor pretende abordar o problema da homossexualidade feminina. Elas trocarão alguns olhares e o problema será considerado ‘já abordado’. A partir de então, a propaganda dirá que esta também é uma novela "controversa" ${ }^{26}$. 3) "Muito triste este capítulo. Desgraça vindo de vários lados [...]. Paloma também estava chateada. Mandou Renata passar a mão no seu rosto e sentir a diferença de idade. Uma tem marcas; a outra é lisa. Começam a trocar elogios. - 'Você é maravilhosa; tem magnetismo'. 'Não! Você é que é linda!'. Talvez seja o início do primeiro relacionamento homossexual feminino do horário. É que já deve existir mercado (Cr\$) para tudo" ${ }^{27}$. 4) "Um jornal carioca mostrou fotografias do casamento de Chico e Paloma. Isso não significa, necessariamente, que eles vão se casar, pois Paloma é do tipo instável e o tal jornal já contou algumas mentiras sobre essa novela. Exemplo: disseram que Paloma (sempre ela) e Renata teriam um relacionamento homossexual"28. 5) "Mesmo com a relativa ousadia que vem caracterizando - além dos capítulos certamente polêmicos de hoje e amanhã [sobre ecumenismo] já insinuou o homossexualismo feminino entre Paloma e Renata, a novela Os Gigantes vem caindo de audiência desde o seu lançamento, dia 20 de agosto: dos 70 pontos iniciais registrados pelo Ibope, desce para 6o, em média, no Rio e em São Paulo"29.

A primeira passagem, publicada pela revista Veja, fala do possível romance entre Paloma e Renata. Durante os primeiros capítulos, esse assunto foi comentado em praticamente todos os veículos, principalmente em colunas especializadas. Percebemos, contudo, que a revista realiza o destaque para o romance lésbico como o primeiro da televisão brasileira, desprezando as representações anteriores, seja no teleteatro ou na telenovela O Rebu.

O segundo, terceiro e quarto fazem parte da coluna 'A novela, ontem', publicada pela Folha de S. Paulo e assinada por JNRJ ${ }^{\text {vi }}$. No segundo exemplo, o crítico realiza um deboche por não acreditar na profundidade da abordagem. Provavelmente, ao perceber o esvaziamento da discussão das multinacionais e da eutanásia, ele concluiu que a relação homossexual também não iria ter repercussão. Estava certo.

No terceiro, o crítico aborda o primeiro gesto, que para ele, caracteriza a homossexualidade na trama. $\mathrm{O}$ jornalista se refere ao capítulo 46, em que Paloma contrata Renata para ser a veterinária de Fênix. Outros dois diálogos, no entanto, deixam mais clara a sugestão de um romance. No primeiro, exibido seis capítulos antes, Renata havia procurado Paloma para pedir dinheiro emprestado com o intuito de quitar uma dívida de Fernando num jogo de pôquer. Ao final, assim foi descrito no roteiro da trama ${ }^{15}$ :

Paloma: (suave). Eu não quero que você vai embora.

Renata: Eu vou sofrer se ficar.

Paloma: Você tem que se enfrentar.

Renata: Como Paloma? Ele te ama...

Paloma: Você tem um mundo tão rico dentro de você... você é tão bonita, tão inteligente, tão sensível... você tem a vida pela frente, você tem a juventude, Renata. Você tem a juventude, tem tudo para ser uma mulher.

Paloma beija Renata

Paloma: Eu quero que você fique...

Renata: É tão bonita essa Fênix.

Paloma: Quero você perto de mim, Renata.

Renata: Perto de você, como assim?

Paloma: Você pode me ajudar muito... muito...

Renata: Eu te ajudar... você nem imagina...

vi Não conseguimos encontrar o nome do crítico, a única assinatura que consta eram as letras 'JNRJ'. 
No capítulo 54, o último com enfoque, Renata já está trabalhando com Paloma. A personagem de Dina Sfat convida a amiga para dizer que havia tomado uma decisão sobre com quem iria ficar: Chico ou Fernando. Diz que a quer por perto. Antes de dizer sua decisão, a veterana pega um anel e diz para Renata adivinhar em que mão ela havia escondido a joia. Contudo, ela faz isso na frente da jovem. Renata descobre, Paloma diz que ela pode ficar com o anel e diz ter escolhido Fernando. Renata chora. Paloma diz para ela não ficar chateada e que Renata deveria confiar nela. Paloma então chama Renata de Paloma. E termina o diálogo dizendo novamente que ela deveria confiar nela ${ }^{\text {vii }}$.

O diálogo não tem um sem sentido aparente, mas podemos inferir uma série de leituras. O anel dado por Paloma é simbólico e remete a um compromisso firmado entre elas. A escolha por Fernando e a troca de nome sutilmente podem revelar um triângulo amoroso. Contudo, a troca de nome e o mistério de Paloma poderiam revelar que a escolha, na verdade, seria por Renata. A continuação desta cena ficou no ar. Capítulos mais tarde, Paloma firma compromisso com Chico. Inclusive, mostra-se dependente dele, sente-se culpada pela morte do irmão e Veridiana, a essa altura, está feroz e trava diversos duelos verbais com a protagonista.

Retornando à crítica de JNRJ, ao fim, ele ironiza dizendo que a inserção da homossexualidade é apenas uma questão de mercado. O debate mercado x cidadania é polêmico, como mostra Jacqueline Dourado ${ }^{30}$. Nossa intenção não é de retomar essa questão, mas gostaríamos de argumentar que não se trata de uma relação excludente. A prática cidadã pode gerar receitas, tal qual uma prática visando o mercado pode ser considerada cidadã. Provavelmente essa não foi uma preocupação de Lauro César Muniz. A inserção da bissexualidade de Paloma foi feita com o intuito de mostrar que sua protagonista não era presa a valores da moral tradicional. Sua liberdade era o seu guia. Seu corpo poderia se relacionar com quem bem entendesse. Especificamente sobre a questão do mercado e padrão de consumo homossexual é nítida a relação estreita. Homossexuais são aproximadamente $10 \%$ da população mundial, um filão no mercado e, certamente, diversas empresas aproveitam, como já foi estudado, entre outros, por Adriana Nunan ${ }^{6}$.

A última referência de JNRJ à homossexualidade foi no sentido de negar a existência dela na trama. Ao que tudo indica, o crítico não considerou o episódio narrado por ele e os outros dois que descrevemos como inserção da homossexualidade feminina na telenovela. De forma contrária, a última inserção que publicamos, retirada do Jornal do Brasil, afirma que a trama abordou a relação lésbica e que partiria para outro tema polêmico, o ecumenismo religioso que se concretiza quando um padre beija a mão e pede a bênção de uma filha de santo da Umbanda.

Regis Cardoso, diretor da trama, em entrevista à Revista Amiga também nega a existência do relacionamento homossexual entre Paloma e Renata: "A: A Globo também teria mandado esvaziar o relacionamento Paloma/Renata? RC: A grande amizade entre Paloma e Renata nunca foi colocada como lesbianismo. A Paloma tinha visão de futuro, sabia que Renata ia ser sua continuidade. Apenas isso" ${ }^{31}$.

É interessante notar a tentativa de 'apagamento' da relação homossexual. Apesar de ela não ter se concretizado, ficou nítido que Paloma estava disposta a ter um romance com Renata. Característica esta, inclusive, apontada por Dina Sfat. Colunistas de TV ficaram divididos, para uns a temática foi abordada e para outros não. No universo da produção, nos surpreendemos com as negações advindas de atores e do diretor. Contudo, e finalizando essa discussão, retomamos a opinião de Muniz expressa em entrevista a Jane Sarques ${ }^{32}$, realizada cinco dias após o término da telenovela global.

vii Ver Fernandes ${ }^{15}$, p. 270-271. 
Você se referiu à moral muito especial da Paloma. Mais no início da novela, houve algumas matérias em jornal e revista que abordavam o relacionamento da Paloma e Renata, atribuindo-lhe uma conotação homossexual. Você tinha a intenção de vender essa imagem, houve alguma mudança na novela em razão disso? (Sarques)

Não, a intenção de vender a imagem de relacionamento homossexual, não. Me passou pela cabeça, enquanto eu redigia a novela, enquanto eu bolava a Paloma, que ela fosse uma pessoa bastante livre e que até a hipótese de um relacionamento sexual com a Renata não estava excluída, entende? Tanto assim que eu disse pra Dina e disse pra Lídia que elas se relacionassem com muito afeto, com muito carinho. Me interessava também esse dado, que ela tivesse até a possibilidade de uma relação homossexual. Mas não que isso fosse uma coisa definida na personalidade da Paloma, ou seja, a Paloma é uma homossexual, isso não. Mas que poderia, também, até ter uma relação homossexual, dada a sua amplitude de universo, entende? (Muniz)

Você recebeu alguma pressão no sentido de cortar isso? (Sarques)

Recebi sim, isso eu recebi sim. Me foi comunicado que eu não abordasse a coisa dessa forma. Foi comunicado à direção da novela que eu amenizasse o relacionamento de Paloma com a Renata. Isso prejudicou bastante o relacionamento das duas que, de certa forma, era também maternal, entende? Eu queria que fosse também uma coisa maternal, que ela moldasse, pelo menos, que ela estimulasse aqueles elementos que a Renata tinha, de uma menina livre, de uma menina independente. Esse aspecto da Renata agradaria à Paloma e ela estimularia isso na Renata. Eu tava preparando justamente a Renata para o final da novela, que era pra receber o filho da Paloma. No final oficial, no final que eu escrevi, quem fica com o filho da Paloma é a Renata. Isso foi modificado, depois, pela estação. (Muniz)

Como o autor aponta, a lesbianidade de Paloma não seria uma marca definidora de sua personalidade e seu comportamento. O romance com Renata seria prova de que ela é livre e dona de seu corpo. Mesmo assim, Paloma se casaria com Chico, que se descobre estéril, e resolve ter um filho com Fernando, mesmo este já namorando Renata. A cena do adultério feminino foi cortada da trama. O filho que Paloma teve foi mesmo de Chico, que havia se 'curado' da esterilidade e realizou um espermograma a pedido de Paloma. Outras duas modificações substanciais foram inseridas da trama. Paloma deveria ter uma filha, que receberia também o nome de Paloma, como a Fênix renasce da Fênix, Paloma deveria renascer de Paloma. E a educação de Paloma II seria de responsabilidade de Renata, mantendo assim um pouco da coerência do forte sentimento que as unia. Assim como o pai (Frederico I), Paloma ao saber de sua condenação pela morte do irmão, sente-se transtornada com a possibilidade de perder sua liberdade, pega o avião de sua fazenda (a Fênix) e sobrevoa a cidade de Pilar até que a gasolina acaba e ela explode no chão.

Uma entrevista ao jornal paulista Shopping News, veiculada no dia 6 de janeiro de 1980, causou a demissão do autor. A partir do capítulo 133 houve modificações nos capítulos, sendo o último reescrito por Walter George Durst. Nesse capítulo, Paloma também morre com a explosão de seu avião, contudo ela tem um filho (Federico III) de Chico. A educação do filho coube à sua cunhada Veridiana, pois Paloma sentia-se responsável pelo aborto que a personagem de Susana Vieira sofrera. Um diálogo entre Chico e o Padre revela que Paloma era neurótica, situação essa não admitida pelo autor.

Após o fim da telenovela, diversos veículos registraram situações propostas pela trama que não foram efetivadas em sua plenitude. Novamente a questão da homossexualidade reaparece. Liane Alves ${ }^{33}$, por exemplo, intitulou sua matéria: "O fim de 'Os Gigantes', uma história de sucessivos abortos”. A jornalista, apesar de não incluir a trama homossexual, aponta três situações que a telenovela começou a mostrar e foram eliminadas: 1) crítica às multinacionais; 2) incesto de Paloma e Freddy, em cenas de flashback ; 3) problematização da eutanásia. Repórteres da revista Amiga, por exemplo, apresentaram a situação como 'aprofundar a amizade de Paloma e Renata', como podemos verificar no fragmento: "Os gigantes parecia mesmo condenado desde o início. Chegou-se a comentar que a Globo minimizou a revolta de Antônio Lucas (Mário Lago) contra as multinacionais. Segundo alguns foi a partir daí que Lauro César Muniz se complicou. Mário Lago entrava com a sugestão de desaparecer com o Antônio Lucas para que 'o público sentisse a força política do personagem'. Lauro resistiu e Mário só conseguiu desligar quando já não tinha mais como transferir uma operação 
nas cordas vocais. Paloma (Dina Staf) e Renata (Lídia Brondi) também foram contidas, quando a direção da Globo recomendou claramente ao autor que não aprofundasse tanto a amizade das duas, caminho que seria inevitável para Vânia (Joana Fomm) e Helena (Vera Fischer), ambas revoltadas com Paloma. Mais uma vez, Lauro teve que ceder. Com a inesperada doença de Suely, mulher de Lauro, os capítulos passaram a atrasar”34.

Mais reflexivo com a relação, podemos notar o comentário de Artur da Távola expresso em sua página também na revista Amiga: "Profissão difícil essa de autor de telenovela! Se faz sucesso é um alienador, um anestesiador do povo! Se não faz, é um subliterato fracassado! Aí o negócio é intrigá-lo com o canal! [...]. Diante desse quadro, é muito difícil, realmente, ser autor de televisão. Esta, mesmo já tendo trazido à baila - com mérito e coragem - problemas sérios como especulação imobiliária, aborto, poluição, juventude, banditismo e criminalidade urbanas, problemas sexuais de impotência ou homossexualismo, lutas de posseiros contra latifundiários e destes com garimpeiros, egoísmo da burguesia, fanatismo religioso e político, ações das multinacionais, problemas sociais etc., mesmo com o mérito de ter realizado tudo isso e muito mais em telenovelas, exatamente na novela em que ficou claro para todo mundo a influência de uma multinacional, esta, a televisão, mesmo com o mérito de ter realizado tudo isso, é atacada por todos os lados e um autor acaba sendo demitido por ser levado a criticar (ou por criticarem por ele) o seu canal. Este, por sua vez, vinha sendo criticado por deixar um autor seu atacar as multinacionais num veículo tão poderoso como a telenovela. Em suma: canal e autores, façam o que fizerem, serão criticados e atacados pela falta de sensatez com que se fala sobre TV no Brasil” 35 .

O cronista critica a demissão sumária de Lauro César Muniz e traz à luz os diversos assuntos polêmicos, alguns tabus, encenados via teledramaturgia, e a homossexualidade foi um dos assuntos elencados. Não sabemos se Távola está se referindo especificamente à homossexualidade em Os Gigantes. Até 1980 a Rede Globo mostrou outros personagens homossexuais de forma relativamente profunda, como é o caso de $\mathrm{O}$ Rebu e do seriado Malu Mulher.

\section{E a censura?}

Como já afirmamos, a abordagem da possível relação afetiva/sexual entre Paloma e Renata fora limada a partir do capítulo 54. Ao consultarmos os pareceres emitidos pela DCDP - em todos os 147 capítulos - não encontramos nenhum corte motivado por relacionamentos homossexuais. O parecer $\mathrm{n}^{\mathrm{o}} 3735 / 79$, assinado pelos censores Eni Martins França Borges e Domingos Sávio Ferreira, responsáveis por analisar os dez primeiros capítulos, apresenta a seguinte conclusão: "Em torno dessas situações abordadas nesses capítulos deverão girar as tramas da novela, destacando-se o 'triângulo amoroso que envolve um homem casado e desdobrase em adultério, conforme previsto na sinopse aprovada, a prática criminosa da autanásia' (sic), a rivalidade entre latifundiários e a presença de uma multinacional sufocando uma pequena empresa nacional. Os capítulos vistos não apresentam situações incompatíveis com o horário das 20:00, podendo ser liberados sem restrições”viii,18.

Uma rápida comparação entre a conclusão desse parecer e as análises realizadas por Guilherme Fernandes ${ }^{4}$ referentes à censura às telenovelas no período de 1968 a 1976 mostra uma disparidade muito grande. Adultério, crimes, situações de revolta social, entre outros, não eram narrativas permitidas nesse horário. Ademais, não houve modificações na legislação censória entre o período analisado por Fernandes e a exibição de Os Gigantes.

Os pareceres desse período geralmente eram compostos por duas partes principais. Primeiro os censores descreviam, brevemente, o enredo apresentado nos capítulos analisados e, na sequência, emitiam uma conclusão, indicando, ou não, cortes. Na parte reservada ao resumo do enredo, poucas vezes os diálogos entre Paloma e Renata chamaram a atenção dos censores. As técnicas de censura Joana S. Passos e Jussara F. Costa, ao analisarem os capítulos 22 e 23 da atração, assim relatam um dos encontros entre as

viii Parecer no 3735/79, 16 ago. 1979, p. 1, destaque nosso. 
personagens: “Casualmente, Paloma encontra com Renata e na conversa entre as duas, descobre-se o envolvimento da jovem veterinária com Fernando"ix,18.

Neste primeiro momento, poucas questões de ordem moral foram objeto de cortes na telenovela. Um dos poucos exemplos - e que não envolvem Paloma e Renata - pode ser observado na seguinte passagem do parecer assinado por Joana Silveira Passos e Yunko Akegava referente ao capítulo 68 (ressaltamos que antes desse capítulo não encontramos cortes similares a este): “As situações apresentadas dão continuidade ao tema proposto na novela. Alguns envolvimentos amorosos deixados implícitos durante todos os capítulos em diálogos e cenas que pressupõem 'amor livre' entre os diversos casais são colocados de forma mais clara em diálogos entre Chico e Helena (pag. 4), e Jaime e Ana (pag. 15), para os quais sugerimos supressão, no entanto, tal situação permanecerá evidente para o público mais adulto mesmo com a eliminação das referidas falas”,18.

Como se pode perceber, nesse curto momento de 'abertura' moral da DCDP, questões que antes (e também depois) seriam fartamente combatidas foram liberadas sem maiores entraves. Para a censura, é como se o romance entre Renata e Paloma não tivesse existido.

\section{Considerações finais}

Ao estudar a telenovela Os Gigantes na 'TV de papel', ficamos na dúvida se esta homossexualidade (no caso, a bissexualidade) existiu apenas no plano das ideias ou se realmente foi transposta para o vídeo. E o espectador? Que subsídios teve ele para encontrar ou não a representação de um amor entre iguais?

Sobre a recepção, o trabalho de Sarques ${ }^{31}$ não sana nossa inquietação. O comportamento libertino de Paloma foi criticado e, certamente, haveria a reprovação da prática homossexual. A nosso ver, a trama mostrou sim que Paloma era bissexual, contudo, a prática da homossexualidade ficou apenas na sugestão. Tal sugestão foi a tônica da quase totalidade das representações em época de censura militar. Fica assim o registro da primeira (e até a exibição de Em Família, no ano de 2014 - a única) protagonista detentora de uma identidade bissexual na trama das 20/21 horas das telenovelas da Rede Globo.

De certa forma, o autor da trama trouxe as características da sociedade dos anos 1970 - as que Kehl ${ }^{5}$ se referiu para o período e que destacamos neste texto. As modificações na sociedade vivenciadas pela pesquisadora e, possivelmente, percebidas também por Muniz, não eram totalizantes, ou seja, havia uma grande parcela conservadora para além da juventude de classe média urbana. Paloma - e seu voo de liberdade - não conseguiu ser compreendida: seja pela atriz, diretor, críticos ou público.

Ademais, cabe ressaltarmos a menção da homossexualidade de Paloma nas publicações impressas que visam resgatar a memória da teledramaturgia da Rede Globo ${ }^{36,37}$. O Dicionário da TV Globo afirma: “A trama abordava temas polêmicos como a eutanásia e o poder nas multinacionais, além de insinuar um interesse homossexual entre as personagens vividas por Dina Sfat e Lídia Brondi. Isso não foi bem aceito pelo público, que considerava as temáticas - em especial a eutanásia - inadequadas para uma telenovela" ${ }^{36}$.

Já o Guia Ilustrado TV Globo ${ }^{37}$ encerra o verbete de Os Gigantes apontando que "a novela insinuava um romance homossexual entre Paloma e Renata (Lídia Brondi)”. É interessante observarmos que entre tantos traços polêmicos da telenovela, as publicações fizeram questão de ressaltar tal insinuação romântica, mesmo que, de fato, a inserção da lesbianidade na trama tenha durado poucos capítulos e tenha sido abortado da trama. Mesmo que a insinuação tenha ficado sutil, a bissexualidade foi um traço da identidade de Paloma e, embora não se saiba exatamente o motivo, o Memória Globo não quer deixar esse laço ‘esquecido’ no processo de memória.

ix Parecer no 4133/79, 10 set. 1979, p. 1.

X Parecer no 5125/79, 31 out. 1979, p. 1. 
É necessário também questionarmos que o verbete da telenovela no Dicionário da TV Globo enfatiza que o público não aceitou a abordagem de temas polêmicos. A eutanásia ainda é assunto tabu na televisãoxi e divide opiniões no ponto de vista da saúde e da religiosidade. A crítica às multinacionais, muito possivelmente, não teria motivos para causar rejeição no público, mas desagradou a cúpula da emissora que poderia perder contratos com anunciantes. O 'romance homossexual' igualmente não foi rejeitado pelo público exatamente pelo motivo de sua não concretização. A consulta que fizemos nos jornais e revistas nos fizeram crer que havia uma rejeição à figura de Paloma, mas não há evidências se tal rejeição fora motivada pela sexualidade da personagem. Atribuímos a não empatia do público com a personagem pelo fato da personalidade de Paloma ser um tanto ambígua e a sua não decisão por Chico e Fernando. Não se pode atribuir ao público uma rejeição de algo que não lhe foi mostrado.

\section{Referências}

1. Bernardo A, Lopes C. A seguir, cenas do próximo capítulo. São Paulo: Panda Books; 2009.

2. Cardoso R. No princípio era só som: a minha grande novela. São Paulo: Madras; 1999.

3. Delgado MT. Dina: por que não matam logo essa mulher? Rev Sétimo Céu (Editora Bloch). 1979 dez;282:6-7.

4. Fernandes GM. Mentalidade censória e telenovela na ditadura militar [tese]. Rio de Janeiro: Universidade Federal do Rio de Janeiro; 2018.

5. $\quad$ Paloma, um perfil feminino na TV. Estado de S. Paulo (Grupo Estado). 1979 ago. 21;27.

6. Nunan A. Homossexualidade: do preconceito aos padrões de consumo. Rio de Janeiro: Caravansarai; 2003.

7. Kehl MR. As duas décadas dos anos 70. In: Risério A, Pereira CAM, Coelho CNP, Freire C, Revah D, Aquino D et al. Anos 70: trajetórias. São Paulo: Iluminuras; Itaú Cultural; 2005. p. 31-7.

8. Hamburger E. Teleficção nos anos 70: interpretação da nação. In: Risério A, Pereira CAM, Coelho CNP, Freire C, Revah D, Aquino D, et al. Anos 70: trajetórias. São Paulo: Iluminuras; Itaú Cultural; 2005. p. 47-52.

9. Sacramento I. La televisión brasilera en los años de la dictadura militar (1964-1985): la higienización del grotesco como afirmación de lo moderno. ReHime 2012 Oct;2(2):53-101.

10. Lopes MIV. Telenovela como recurso comunicativo. Matrizes 2009 ago.;3(1):21-47.

11. Silva JFB. Homossexualismo em São Paulo. In: Green JN, Trindade R, organizadores. Homossexualismo em São Paulo e outros escritos. São Paulo: Unesp; 2005. p. 39-212.

12. MacRae E. Em defesa do gueto. In: Green JN, Trindade R, organizadores. Homossexualismo em São Paulo e outros escritos. São Paulo: Unesp; 2005. p. 291-308.

13. Moreno A. A personagem homossexual no cinema brasileiro. Niterói: UFF; 2001.

14. Lima DM. Os homoeróticos. Rio de Janeiro: Francisco Alves; 1983.

15. Fernandes GM. A representação das identidades homossexuais nas telenovelas da Rede Globo: uma leitura dos personagens protagonistas no período da censura militar à televisão [dissertação na Internet]. Juiz de Fora: Universidade Federal de Juiz de Fora; 2012 [citado em 2019 jan. 31]. Disponível em: https://repositorio.ufjf.br/jspui/handle/ufjf/2028.

16. Simões JA, Facchini R. Na trilha do arco-íris: do movimento homossexual ao Lgbt. São Paulo: Perseu Abramo; 2009.

17. Queiroz A. TV de papel: a imprensa como instrumento de legitimação da televisão. 3. ed. São Bernardo do Campo: Cátedra Unesco; 2010.

18. Moreira SV. Análise documental como método e como técnica. In: Duarte J, Barros A, organizadores. Métodos e técnicas de pesquisa em comunicação. 2. ed. São Paulo: Atlas; 2006. p. 269-279.

xi Apenas recentemente o assunto voltou a ser introduzido na teledramaturgia. A minissérie Justiça, de Manuela Dias, exibida pela TV Globo em 2016, às 22:30 mostrou o fato por meio do personagem Maurício (Cauã Reymond) que praticou a eutanásia em sua esposa Beatriz (Marjorie Estiano) que havia ficado tetraplégica. 
19. Arquivo Nacional (BR). Divisão de Censuras às Diversões Públicas. Série: Programas de Rádio e Televisão. Subsérie: Telenovela. Caixa: 73. Brasília: O Arquivo; [19-?].

20. Leme L. Dina Sfat: minha força está na minha cabeça. Amiga TV Tudo (Editora Bloch). 1979 set. $12 ; 486: 4-6$.

21. Leme L. Lídia Brondi: "Não sou ninfeta!". Amiga TV Tudo (Editora Bloch). 1979 out. 17; 491:4-6.

22. Santos JF. Dina Sfat: "Ser heterossexual é bom". Veja (Editora Abril). 1981 set. 30;682:3-6.

23. Angel H. Por dentro da TV. O Globo (Grupo Globo). 1979 out. 22:28.

24. A nova novela de LCM: ódio, medo, amor, ambição: as raízes das paixões humanas. O Globo. (Grupo Globo). 1979 ago. 20:19.

25. Com a cara lavada. Veja (Editora Abril). 1979 out. 03;578:64-5.

26. JNRJ. A novela, ontem: os gigantes. Folha de S. Paulo (Grupo Folha).1979 set. 08:26.

27. JNRJ. A novela, ontem: os gigantes. Folha de S. Paulo (Grupo Folha).1979 out. 12:42.

28. JNRJ. A novela, ontem: os gigantes. Folha de S. Paulo (Grupo Folha).1979 nov. 21:34.

29. Aragão D. Ecumenismo polêmico. Jornal do Brasil (Omar Resende Peres Filho). 1979 out. 26; Caderno B:1

30. Dourado JL. Rede Globo: mercado x cidadania? Teresina: Ufpi; 2010.

31. Lauro César Muniz: 'o filho de Paloma tinha que ficar com Renata e não com Veridiana'. Amiga TV Tudo (Editora Bloch). 1980 fev. 20;509:10-1.

32. Sarques J]. A ideologia sexual dos Gigantes [dissertação]. Brasília: Universidade de Brasília; 1981.

33. Alves L. O fim de "Os Gigantes" uma história de sucessivos abortos. Estado de S. Paulo (Grupo Estado). 1980 jan. 13:37.

34. Risemberg A, Coelho L. Os Gigantes: no final, mais emoções nos bastidores. Amiga TV Tudo (Editora Bloch). 1980 fev. 13;508:10-11.

35. Távola A. Profissão difícil essa de autor de telenovela! Amiga TV Tudo (Editora Bloch). 1980 fev. 07;507:66.

36. Memória Globo. Dicionário da TV Globo: programas de dramaturgia e entretenimento. Rio de Janeiro: Jorge Zahar; 2003. p. 97.

37. Memória Globo. Guia ilustrado TV Globo: novelas e minisséries. Rio de Janeiro: Jorge Zahar; 2010. p. 102. 